\title{
FREEDOM OF PRESS AND JUDICIARY CENSORSHIP IN BRAZIL
}

Marco Aurelio Peri Guedes

\begin{abstract}
The author has an undergraduation degree conferred by Law School of State University of Rio de Janeiro (UERJ) in 1994. Master's Degree (LLM) in Theory of State and Constitutional Law by Pontifical Catholic University of Rio de Janeiro (PUCRIO) in 1997. Attorney at Law with practice in Rio de Janeiro from 1998 to 2009. Professor of law at PUC-RIO (1997), FESO (2000-2001) and UCAM/CENTRO (1997-2009). Since 2010, Full Time Assistant Professor of Constitutional, Administrative and Environmental Law of Federal Rural University of Rio de Janeiro (UFRRJ).

marcoguedes3@gmail.com
\end{abstract}

\begin{abstract}
This paper intends to provide an overview on freedom of press under the 1988 Brazilian constitution. Despite living the longest democratic term of Brazilian history - twenty seven years so far, the constitutional and democratic project are under a clear and present threat, this time coming from an unsuspicious player in the democratic game: the judiciary branch of the state. The 2009 Estado de São Paulo case reflects how such threat has been identified by some justices belonging to the Brazilian supreme court - the S.T.F. - committed with a democratic and constitutional culture. The threat is scattered all over the land, coming from individual members and sometimes from several states' appeal courts of both state or federal degrees. Either we enjoy plainfully the fundamental rights or we do not live in an actual democracy, in the western liberal and bourgeois concept of it. Becoming aware of it, rising up legal resistance against such threat and spreading the news for the whole citizenship is a necessary step to consolidate democracy in Brazil and to push away authoritarian political regimes.
\end{abstract}

Keywords: Brazil -October 5, 1988 Brazilian constitution-Fundamental rights - Freedom of press - Censorship - Judiciary censorship - The 2009 O Estado de São Paulo case - Freedom of press under liberal and non liberal post 1988 Brazilian governments 


\section{INTRODUCTION}

This paper aims to give the reader a panorama on the freedom of press in Brazil from the times of colony through Empire until after 1982 new democratic regime. In the early moments of the so called New Republic - born with the constitution enacted by the Congress on October 5, 1988 -came the opening for a new democratic living experience. It was expected by civil society the Executive branch would no longer interfere with the press. But daily life in some regions of Brazil brought to the world of facts several distorted decisions taken by judges of the Judiciary branch establishing prior and post publishing Judiciary censorship. The climax of this distortion came with the case of the São Paulo daily newspaper O Estado de São Paulo, one of the most important and prestigious in Brazil.

The $O$ Estado de São Paulo reaches the peak of the main issue here. A simple operation conducted by the Brazilian Federal Police on 2009 found out and arrested many persons with links to high grade politicians in the Brazilian National Congress, beyond persons linked to police organizations, law firms and etc. The journalistic cover conducted by that daily newspaper got repercussion because one of the allegedly involved was the son of Brazil's Federal Senate President, Senator and former President of the Republic - José Sarney. With the journalistic cover the daily newspaper begun to suffer many sorts of retaliation. Judiciary censorship fell over the news and lasts until now. The case is at the Brazilian Supreme Court to be judged, but not in schedule so far. Our intention is to follow the chain of events and expose the issue for analysis.

\section{A PANORAMA ON FREEDOM OF PRESS AND CENSORSHIP IN BRAZIL}

A fast panorama on freedom of press is necessary to enlighten the issue in Brazilian History. Since 1500 with the arrival of Pedro Álvares Cabral and the first settlers on the Brazilian shore the Portuguese Empire imposed royal censorship. Publishing and printing equipment were prohibited. With independence from Portugal and the foundation of the Empire of Brazil (September 7, 1822) to republic proclaimed (November 15, 1889) Brazil lived some liberal period for the press to grow free. The proclaimed republic represented the political well succeeded pact between the two major landowners elites in the country, situated in the federal states of Minas Gerais and São Paulo. The pact was denominated the Coffee and Milk Policy. This pact established the appointment and election for President of a representative of each of these two states, in different turns regardless of the other federal states interests, claims or will. The ideals of republic and democracy were 
just ideas and part of a political farce. This was the Old Republic which lasted until the 1930 Revolution'.

The so called 'Old Republic' endured until 1930, when the landowners rule inside the political life begun to lack political support from different sectors of society exhausted by the pact as it was. The 1930 revolution put an end with the Coffee and Milk Policy and Getúlio Vargas was its main leadership. The revolution promised to draft a new constitution for the country. After two years and no constitution on sight a counter revolution started in São Paulo, which claimed for the constitution. The light and fast São Paulo civil revolution happened on $1932^{2}$. São Paulo was militarily defeated, but a new constitution was drafted on $1934^{3}$. After a short three years lifetime Getulio Vargas as the supreme political leader imposed the constitution of $1937^{4}$. The war begins in Europe on 1939 and Brazil aligned with United States sends one army division and one air group to fight in the Italian war front ${ }^{5}$. The war finishes on august 1945 and Getúlio Vargas was deposed.

Democracy comes again on 1946 with a new constitution. For some time the country finds development and political stability. The post second war world displays the international political order divided between the United States of America and the Soviet Union, a division between capitalists and communists. The 1946 constitution lasted until the military intervention and government on 1964. The intervention wanted to put an end in the communist influence rising in Brazil, as sponsored by the Soviet Union and Cuba. A constitution was drafted

1 This pact is known as the Coffee and Milk Policy, because São Paulo and Minas Gerais were the richest federal states at the time. The first one was the biggest coffee farm state and Minas the biggest Milk producer. The coffee income would boost São Paulo's industrial revolution after 1920. Until now São Paulo is the most industrialized federal state in the Brazilian federation.

2 The constitutionalist revolution of São Paulo, which demanded from the provisory government of Getúlio Vargas the commitment on drafting a new constitution as stated by the 1930 revolutionary movement before.

3 The 1934 constitution opened the door for the social rights in the text, designing anew Title on the constitution named Social and Economic Order. The new rights were to protect the family, the youth, the woman and the workers. It was influenced mostly by the 1919 German Weimar constitution.

4 The 1937 was just a pro forma constitution, never to be applied. It was based on the polish constitution drafted by Marshall Pilsudski. It was a dictatorial constitution. The power of the president was increased to keep Getúlio Vargas in office. In political terms, he was ambiguous with both dictatorial regimes such as Nazi Germany and fascist Italy and democratic USA.

5 The Brazilian expeditionary force was composed of twenty thousand troopers and one air fighter group. It was completely equipped, trained and at last transported by the United States into Italy on late 1944 . The Brazilian division was attached to the $5^{\text {th }}$ American Army commanded by General Marck Clark. It captured four German and Italian divisions. The air fighter group was awarded the U. S. Presidential Honor Citation by gallantry and outstanding action against enemy forces. 
and imposed by the military leaders on 1967 and got emended on 1969. All this time political censorship was everywhere in Brazilian society, mainly from the Executive branch controlled by the military. The other branches of the State didn't oppose resistance.On 1982 the last military President General Figueiredo passed the power to civilian politicians.

The 'New Republic' as denominated was founded on 1986 with the presidency of José Sarney - former allied to the military government - and new democracy term begun with the constitution enacted on October 5, 1988.

Democratic living in the Brazilian history has been often interrupted by unsolved internal political crisis and conflict of interests between several political factions whether if they are in power or not. As a consequence some political institutions lack the basic values of a continuous democratic expertise. Bonds of commitment with democracy and constitution are feeble.

\subsection{Brazil's historical and political backstage and Judiciary branch}

It is a common ground for Brazilian historians and political scientists that Portuguese settlement in Brazil during four centuries rooted in the colony rulerswith political vices and corrupted views. Such enrooted vicesled to misconceptions on how to deal with both State authority and treasury assets. To control a vast territory of more than three million square kilometers the Portuguese crown gave full authority and no limits for its rulers. The practice of organizing territory in Capitanias ${ }^{6}$ established on people's mind the idea that State and all within it belonged to the ruling Donatários ${ }^{7}$ families. The same line of thinking remained during the Empire of Brazil (1822-1889) $)^{8}$ and it lasts for the whole Republic term (1889 -present days). Its resilience is due to the ability on building allegiances and promote political take over at all costs.

6 In the first centuries of settlement and Portuguese territorial expansion, the Portuguese Crown divided the territory in latitude from seashore inland until the line set by Portugal and Spain in the Treaty of Tordesilhas, from the XVI until the XVII century, when this system was abolished by the Marquis de Pombal.

7 Donatários mean 'Grantees' of the Portuguese Crown, in charge of a certain slice of territory or Capitania, with full authority to settle and develop it. Extraction of minerals, gems and all sorts of foods were to be exported to Portugal. Black slavery from Africa was massively introduced in the colony to accelerate development and to perform the task. Between the XVII and XIX century it is said that Brazil received five million black slaves while USA received five hundred thousand.

8 The Empire of Brazil was founded on 1822 with Independence. Dom Pedro I, son of Dom João VI - King of Portugal, broke the bonds with the Portuguese Empire and created his own monarchic dynasty which lasted until 1889 when his son Dom Pedro II was removed from power by the proclamation of the Republic on 1889. At the time the Brazilian Empire was considered bigger in size then the British Empire, but all concentrated in one main continental territory. 
The idea of Republic brought to Brazil after 1889 was very much based upon the conception raised with the 1789 French revolution. However, this vision of world only grew widely between the military personnel who embraced its philosophical values ${ }^{9}$. Civil society remained controlled by politicians attached to their Patrimonialism ${ }^{10}$ colonial mentality as political sciences defines it ${ }^{11}$. To understand the meaning of the word is to understand Brazil. In some regions in Brazil some political ruling families for over decades and maybe centuries truly think State's power and influence belong to them as personal property or an extension of their personal assets. For them the actual sense of Republic doesn't exist and the rule of law do not apply to them.

There is a permanent clash between in one hand modern sectors of society enlightened by good quality and refined education, embedded re publican values, which travels the world with a clear understanding on how a modern Republic ${ }^{12}$ shall be; and in the other hand underdeveloped 'colonial'narrow minded sectors of society, whose political dominance prevails by imposing ignorance, poverty and illiteracy over the people. In what affects the State and more specifically the Judiciary branch some of these politicians are historically so influent justices' appointment for the Judiciary branch are sometimes determined by political non republican allegiance factors. By doing so these politicians 'fill the blanks' of the State to possibly grow influence inside the Judiciary branch $^{13}$, its relations with other branches of the State and Republic's

9 Brazilian Navy and Army embraced the Republic seeing an opportunity to grow influence within the State. As the civilians didn't manage to get organized and build a project of nation, the military staff always behaved as a last resource to solve all political crisis and 'save the country'. The Lieutenant movement will make a stand in the 1920-1930 liberal revolutions, mostly and highly influenced by similar movements as the Kemalism in Turkey, founded by Mustapha Kemal Ataturk, the founder of the modern Turkey.

10 Patrimonialism is a conception of the State typical from European middle ages. It represents a confusion between the personal belongings of the ruler and State's assets in order to favor the ruler and his family and the group nearby.

11 Practice in dealing with State and its resources as if they were part of the ruling family personal assets, and to profiteer from it at all costs and with all means possible, regardless of accountability to society.

12 As a quick reference for the reader, 'republican' here means the French revolution concept of republicanism thought, not the political dichotomy used in the US between democrats and republicans.

13 Just as an example the C.N.J. - National Judiciary branch Council in charge of performing the external control of the Judiciary branch across the country opened the Proceeding of Administrative Control n. 510 to investigate fraud on the public exams for Judges in the federal State of Rio de Janeiro, on 2006. The Rio de Janeiro State Court of Law opened an internal investigation which came to the conclusion of no fraud whatsoever. Then, the C.N.J. was called to intervene due to a plea of partiality. The C.N.J. has a mixed composition of judges from different courts, district attorneys and lawyers appointed by the Brazilian Federal Lawyers 
institutions. At the utmost extreme they may influencethe interpretation of the law favoring their interests.

According to law dogmatic sovereign power is unique in the whole territory. The Judiciary branch is an expression of this power and it is only one ${ }^{14}$ in the whole country, but not the same. The political and administrative organization of the Brazilian State ${ }^{15}$ reflects twenty seven states in the federation. Each one has a Federal Court of Law to judge cases in which the Union has an affected claim or interest.Excluding the federal jurisdiction for the issue ${ }^{16}$, the State has a local Court of Law to judge civil, criminal and other kinds of cases. As pointed out above, as established by the 1988 constitution each one of these Courts has to coordinate and select young judges to the court through public exams. In some states and in many occasions frauds in these exams have already been reported.

Brazil is a land with many countries inside. Due to the size of the country its geographical peculiarities and uneven degrees of socio-economic development are clear.The people features different historical backgrounds according to the predominant ethnic group and other variables on the political backstage which are almost impossible to list up here in this paper. The 1988 constitution itself recognizes the importance of the main ethnic groups in the formation of the Brazilian nation ${ }^{17}$, which were the multiple native Indian tribes, the African slaves and the many European immigrant settlers who came to the country between 1500 and $1950^{18}$. At this point is more than convenient to remember MONTESQUIEU pointing out the influences of natural, historical and geographical variables in the formation of

Bar Association. The public attorney in charge to report the case Felipe Cavalcanti came to the conclusion of fraud in the exams. The Brazilian Federal Lawyers Bar Association supported its branch of Rio de Janeiro on the claim for cancelling the exams. At the C.N.J. session on the case the Federal General Attorney supported the claim for cancelling based upon the Federal Police evidences gathered. The claim was denied at the C.N.J. due to internal political interests. The representative of the lawyers at the C.N.J. stated that at the end a corporate decision was taken. See: http://www.conjur.com.br/2008-fev-26/relator_cnj_houve_fraude_concurso_rio. Access on June 6, 2015.

14 As an expression of sovereign power it cannot be understood as a fragmented power over the territory. Only its organization seems to give such idea, because it is organized in federal and state levels, determined by the presence of economic or procedural interest of the Union. If the Union has no interest on the case, then the state judiciary branch is the competent one to decide the case.

15 Articles 19-35, Brazilian 1988 constitution.

16 The federal jurisdiction is listed on article 109 of the 1988 Brazilian constitution.

17 Brazilian constitution: Article 216. Compose the Brazilian cultural inheritance the assets of material and immaterial nature, taken individually or in group, bearers of reference to identity, to action, to memory of the different forming groups of Brazilian society, (...).

18 Portuguese, Germans, Italians, Japanese, Ukrainians, Armenians, Turkish, Lebanese, etc. 
the law of a land ${ }^{19}$.

All this human melting pot picturing Brazilian society was somehow ruled by representatives of the Portuguese crown during the colonial term (1500-1822) - Independence: September 7,1822; representatives of the provinces during the Empire (1822-1889) and representatives of the Republic since its foundation (November 15, 1889). Many different claims on the fields of politics, social and economic levels have to be conciliated and ruled. Even after independence these families which 'ruled' specific regions of the country remained in power, directly in office or indirectly influencing politics due to its wealth. They were clearly identified as oligarchs by contemporary Brazilian historians ${ }^{20}$. They are still known as the Coronéi ${ }^{21}$ of the politics, which led to the expression coronelismo ${ }^{22}$ on the Brazilian political sciences ${ }^{23}$.

\section{THE FREEDOM OF PRESS UNDER THE BRAZILIAN CONSTITUTION OF OCTOBER 5, 1988}

The 1988 constitution in the head of article 5 establishes that freedom is one of the citizen's fundamental rights and shall be guaranteed by the State. Freedom is a value chosen by 1986 constituent assembly to be protected. The idea was to avoid a revival of an authoritarian or dictatorial experience, which so many times took part of the Brazilian history ${ }^{24}$. Under such historical point of view, freedom

19 MONTESQUIEU. The Spirit of the law.São Paulo: Martins Fontes. 4 ed.2005.

20 FAORO, Raimundo. Os donos do poder. São Paulo: Globo, 20--. GOMES, Laurentino. 1808. São Paulo: Globo, 2013. From the same author: 1822 and 1889.

21 'Colonels'= military army commission.

22 A new form of imposing personal will through the force, sometimes paramilitary force, all out of the rule of law.

23 Coronel in portuguese means Colonel, the highest military commission before General commission. It comes from the imperial time, when big farmers and landowners across the land bought from the imperial authorities the commission of Colonel of the Freewill Army Core, a reserve of the Brazilian imperial army. Since then the farmers remained known as such. Despite these commissions are no longer valid, the use of the word persists to point out a no modern republican politician, but an old one attached to bad political practices. In so doing, then comes the expression Coronelismo which reflects an authoritarian person with no respect to the democratic political institutions or procedures, insisting upon a behavior margining the law, sometimes out of law. To get more acquainted on the issue it is recommended the work of the famous north-american brazilianist Thomas Skidmore.

24 It shall be informed to the reader the rule of exception to lawin Brazilian constitutional history was 1937-1945 and 1967-1982. The period 1822 to 1889,Brazilian Empire - was a constitutional monarchy pro forma - a constitutional euphemism - because it was not like anyexisting modern European constitutional monarchy. Nevertheless, Brazilian Imperial constitution strongly influenced the Belgian constitution of 1832 in the chapter of the fundamental rights. 
is an object of people's desire since the Inconfidência Mineira ${ }^{25}$, but had to pass through many terms of illegitimate governments, suspended fundamental rights and rules of exception until becoming a reality in the current constitutional frame.

The notion of freedom carved by the fathers of the 1988 Brazilian constitution projects itself in the widest way possible, although not in an absolute way. Citizens shall be educated to exercise their rights by accepting the idea that some of their fundamental rights might be moderated and adjusted by other fundamental rights when in conflict. It shall be remembered the Brazilian constitutionalism does not admits or conceives the existence of absolute fundamental rights. In many occasions daily law operators - lawyers, judges and public attorneys have to deal with edging cases dealing with fundamental rights collision. To preserve all fundamental rights in the concrete case in all senses, a judgment of moderation becomes necessary. It is necessary to decide according to the case and its circumstances and further choosing which one shall slightly prevail, without suppressing the other.

I would like to approach the concepts of property and freedom. When studying civil law at law school it is taught that property obliges. The landowner shall create a bond with the property, real state or a mobile object, by performing all necessary measures put by the law of the land in order to express its dominium over the $\boldsymbol{r e s}^{26}$. Such commitment to property reflects itself by the maintenance of the res in good conditions of use, by the payment of related property taxes and fees, as well as by bringing to effectiveness the sense of 'social function of the property" 27 in the terms of the current 1988 constitution. In a similar way, it is possible to state that freedom obliges all citizens of the polis. In this case the commitment with freedom and democracy shall be devoted by the citizenship unto democratic institutions: the respect to the law, the respect for other citizens, the high consideration to republican values ${ }^{28}$,

25 Movement of Independence which took place in the province of Minas Gerais, during the Portuguese colonial rule. The riot failed and its leaders were hanged and chopped with further exhibit of their pieces on the street according to the Portuguese law. Tiradentes was one of the ringleaders and was martyrized and lasts as an icon of freedom in Brazil. Tiradentes is considered a national hero.

26 Dominium $=$ dominance. Res $=$ thing.

27 The 'social function of the property' is a conception established by the 1988 constitution. It reflects a leftist influence over the liberal conception of the property. The constitution guarantees and establishes that State shall protect the property (article 5). Nevertheless, its landowner shall carry on giving the natural use of it for the generation of wealth for society and not as a way to accumulate and speculate with it. Expropriation measures are listed in the constitution for unproductive farms, farms and lands used for narcotic plantations and urban properties not properly used or empty - in this case the Lei 10.257/00 - Estatuto da Cidade (Statute of the city).

28 'Republican values' in the sense used here guards no relation to the U.S. Republican party. 
the maintenance and constant renovation of the civic spirit and the daily handling with freedom within its legal boundaries.

Property and freedom are two of many political liberal values left to us as a constitutional legacy of the XVIII century liberal revolutions and which were inserted in all Brazilian constitutions since 1822. The birth of these values are the American (1776) and French (1789) revolutions.Property and freedom are the main guidelines of political liberalism and liberal democracy is the very stronghold of them. With a ring of fundamental rights in the constitution it is possible to hold any threat to property and freedom coming from the State, any of its branches or clerks. In this issue the British 1215 Magna Charta Libertatis shall be remembered as the starting point and the highest paramount of it in the very birth of constitutional law.

Freedom of expression consists on a great achievement of the liberal revolutions. It means the public and subjective right of the citizen to express and to spread his thoughts, opinions and conceptions to the world, without the lightest fear of suffering any sort of reprisal neither from other citizen nor from the State. However, such freedom shall be made compatible on its exercise with different opinions and other citizens' thoughts so creating an atmosphere of plural ideas and political tolerance. By exceeding this freedom calls the proper sanction according to the law of the land.The freedom of expression is one of the ways through which an individual develop its personality. Through freedom of expression citizens interact with each other in society exchanging reflections, ideas, opinions, analyzing political proposals and being criticized. Its very existence recognizes clearly the plural and democratic society which is brought to us by the constitution.

Freedom of press is one dimension which derives from freedom of expression. With Guttenberg's technological innovation the possibility to spread ideas and thoughts reached a scale never seen before. Nowadays with the digital means of the information age it is possible to find in the printed media or daily newspapers amongst other digital media channels the very instruments capable of capturing and speeding up public debate of ideas in large population countries. And this is not all. Knowledge in a higher scale makes available to governments the necessary means to provide a good civic education, awakening and turning the people to behave in a more civic manner. In the era of information all digital means available open new frontiers for the freedom of expression and for press. Access to multiple sources

The reference here is to the symbols and values of the republic as a form of government in opposition to monarchy, as spread by the French revolution in the world after 1789 and the roman republic prior to that. It means transparency in the deal with public treasure and public services, respect to democratic rule and institutions, citizenship and its obligations to the state and the constitutional umbrella of fundamental rights. 
of information coming from all sides and lands somehow contribute to shape the well informed citizen of the century.

In Brazil printed press and any related equipment was forbidden by the Portuguese crown until the nineteenth century, as stated before. With Brazil's independence (1822) and during the empire freedom of press was exercised with some moderation ${ }^{29}$. Only with the Republic on $1889^{30}$ freedom of press was considered to be fully protected by a constitution. Censorship came back with the 1937 constitution imposed by Getúlio Vargas lasting until democratization on 1946. With the cold war and military intervention on politics censorship came back on 1967 lasting until 1982, to definitively be banished in all forms by the 1988 constitution. The political stage in South America follows a similar story. Nevertheless, despite the renewal of democratization and the creation of new constitutional pacts all over South American continent in the 1980-1990 decades, it is possible to notice a clear and present danger to press, freedom and democracy.The reason might be the failure of the new democratic political projects in some Latin American societies on delivering people's social and economic claims. Such gap in the social tissue opened the path for the existence of 'semantic constitutions' in the sense deployed by LOEWENSTEIN ${ }^{31}$.A turn to the left was made in some countries. Such turn is known as the "new Latin American constitutionalism'.

As printed press and new media cover and follow the political world, governments in office refuses to accept the work of the media and its investigative role. The scenario portraits in some cases harsh measures taken against press such as murder of journalists and news shut down, overtaxing and bureaucratic obstacles. In Brazil a concrete threat from the State to press and freedom of expression cannot be seen in ashort period. On the contrary, most of the times the threat comes from the power which should be guaranteeing and protecting it from authoritarian politicians, i.e. the Judiciary branch of the State. Some cases came to light on the last twenty years demonstrating judicial decisions with no ground on law or the constitution and making no reason or point at all. Local judges in some counties inland and AppealCourt's judges sometimes perform unreasonable and unexplainable decisions to restrain the press work. The most expressive case is the one involving the daily news $O$ Estado de São Paulo, which is under siege since 2009.

29 As a curiosity for the reader Hipólito da Costa is considered the founder of modern Brazilian printed press, having created the Correio Braziliense in London in the beginning of the nineteenth century, through which he defended liberal ideas for Brazil.

30 Proclamation of Republic in Brazil: November 15, 1889.

31 LOEWENSTEIN, Karl. Teoria de la constitución. Barcelona: Ariel, 1992.The semantic constitution is the one which reflects ontologically reality as it is, in order to preserve the power and its benefits for those who profiteer with it. 
On 1982 with the beginning of transition to democracy freedom of expression and freedom of the press were back again in Brazil under a new democratic context. Later with the new 1988 constitution the liberal concept for freedom of the press was repeated. Brazilian society seemed to be living a new path to become a more democratic nation. Daily newspapers began to demand transparency of the public administration and accountability of bureaucrats and politicians. The struggle against corruption and bad political influence in all instances of power or state bureaucratic mechanisms got more intense. Schemes and detour of budgetary assets were identified all over in an uninterrupted chain until now. Within the schemes persons were spotted and identified linked to politicians, legal firms, etc. The reaction against this press 'controlling police action' was to be built by politicians in office in the Courts. Censorship coming from the State belonged to the dictatorial past. The solution found was to impose a sub poena to the media and newspapers from publishing anything involving the name of politicians and its schemes.

At some point many judiciary decisions contrasted with the values of freedom of the press protected in the constitution. Countless cases were put into courts to set the boundaries on the constitutional freedom of the press. It might seem pointless and too obvious go to a court of law to prove a daily newspapers can publish a fact of public interest involving bad administration of public funds, detour of treasure assets or anything else in the same tone in a democratic environment.

The most symbolic case came into light with the Operation Boi Barrica developed by the Brazilian Federal Police. The reader shall focus attention for the bizarre situation which became common ground in Brazil, i. e., the Judiciary branch imposing censorship onto freedom of the press and violating the public liberties assured by the constitution. In some regions in Brazil, local judges attached to oligarchic families commonly decide restraining the right of small local media newspaper on publishing ideas and comments contraries to their interests. These local judges are many times upheld by their superior local State Courts. The situation takes another proportion when the same path is taken to submit one of Brazil's biggest and most respected daily newspaper to the same restriction. This is the case of the news O Estado de São Paulo, in the federal State of São Paulo, which on 2009 was object of a sub poena to restrain the publishing of any comment, information or names involved in the Operação Boi Barrica conducted by the Brazilian federal police ${ }^{32}$. According to the Brazilian federal police - the Brazilian

32 Here is a chronology of events for the reader.On June 2009 the Estado de São Paulo publishes journalistic cover related to 300 secret acts and administrative decisions within the Senate, kept locked in a secret room, involving assets management and illegal payments made by the Federal Senate compromising public treasury. On July 2009 Brazilian Federal Police begins Operação Boi Barrica. The Distrito Federal High Court justice Desembargador Dácio 
equivalent to the U.S. - F.B.I. - there were signs of involvement of the Brazilian businessman and entrepreneur Fernando Sarney, son of Senator José Sarney - at the time President of the Brazilian Federal Senate - in many illegal and criminal actions.

After more than twenty seven years of democratic renewal it is shocking and outrageous to see the constitution being violated to what relates to freedom of the press in such a basic and oblique manner. This Judiciary branch censorship was conceived bypassing the constitution and procedural law. It is more surprisingly to see that it remains up to now. The daily news $O$ Estado de São Paulo continues under legal siege on this issue. The decision was taken by the Distrito Federal Appeal Court's Justice Dácio ${ }^{33}$, who was appointed some time before the case by Senator José Sarney.

\subsection{Reflections on the freedom of press in Brazil in the last years}

Printed press always had problems with dictatorships and political exception regimes all over the world. And in Brazil the story is no different. The press was under censorship during the military rule between 1964 and 1982. After the last General President João Figueiredo have left office on 1982 to a civilian elected by an Electoral Collegiate in the Congress, things changed in the political scenario. The civilian was Tancredo Neves and his Vice was a former pro military rule politician named José Sarney, coming from the federal State of Maranhão. Tancredo died before taking the presidential oath to the current constitution of 1969 and his Vice José Sarney took place on presidency with the support of the Minister of the Army General Leônidas. Transition into democracy and the rule of law was to be effective and a constituency was to be called to draft a new constitution.

The new constitution was proclaimed on October 5, 1988. Ulisses Guimarães is considered the politician responsible for

Vieira - appointed to office by Senator José Sarney - establishes a restraining order on the news to prohibit any further publishing or journalistic cover related to the federal police operation. The news requires suspicion of the justice due to the link with Senator José Sarney, whose son was supposedly involved in the scheme. The justice in charge of reporting the case Waldir Leôncio declares justice Dácio suspect to decide on censorship over the news. On October 2009 the Special Council of the Distrito Federal Court holds Dacio's decision on censorship. On December 2009, the news proposes constitutional action Reclamação in the Brazilian Supreme Court, which denies the injunction order. The news then decides to hold the constitutional action until final judgement of the issue so the Supreme Court can speak if such procedural decision constitutes or not judiciary censorship.

33 The Federal Court in the capital city of Brazil, Brasilia. The constitution of 1988 allows the fulfillment of some places in high courts of justice by political appointment. Many of these appointed justices who were lawyers, law professors or attorneys in their prior life bring to court with them their corporative interests and some sort of thankfulness by their appointments. 
coordinating the constituency work and to articulate all political demands harmonically in the constitutional text. With the new constitution the 'New Republic'was officially founded putting side by side liberal and social values in what is considered a social-democratic transitional constitution. The preceding pieces of legislation referred to the press and its exercise were considered received due to material compatibility to the new constitution. Printed press had already a legal and a constitutional framework to deal with, respecting the fundamental right of privacy and what was to be considered a professional exercise of the press to apprize society ${ }^{34}$.

\subsection{The unexpected censor in democracy: the Judiciary branch}

With democracy the following of the public administration by the press allowed to build a higher control by civilian society over the state and politicians. Politicians started to be object of criminal persecution due to misgovernment of public treasury funds by public district attorneys, on both state and federal levels. Sometimes these actions failed to prove politicians' guilt according to the procedural law, what doesn't implies in absence of guilt of their behavior on dealing with public funds. In these cases, many politicians got convinced that civil actions to seek for reparations were not enough to constrain the job of the press.

The path was open for politicians to put some pressure over the Judiciary branch in order to obtain restraining orders or sub poenas with county judges or Appeal Court's judges sympathetic or thankful to their appointments to high Courts ${ }^{35}$. An unexpected situation emerged,

34 The constitution set a frame to avoid and to punish the exercise of a free press off the limits, which might cause damages on people's life. Just as a reference to the issue is the remarkable case of the Escola de Base in São Paulo. On 1994 the owners of a child private school for children were falsely accused of pedophilia. Police agents in charge of the case turn public into press initial and wrong conclusions on the guilt of the accused ones and the school was invaded and damaged and the accused were almost killed. The judiciary determined state authorities to appoint another Marshall for the case and the conclusion was the accusations were false. The entrepreneurs lost much of their economical wealth proofing their innocence and even suiting the state for damages they never recovered their prior social condition. Moral and emotional effects tormented then until their deaths. This case is a legal mark for both the judiciary police and judiciary branch on how to behave when performing an investigation which affects people's lives. Nobody shall be considered guilty or previously 'convicted' by personal subjective opinions or judgements of value before the case is submitted in a court of law.

35 To give the reader a clearer idea on how the judiciary branch sometimes put itself in the Brazilian political board, here is an interesting interview bonding law and politics. "The censorship issue is the same on the Senate's crisis". This is the interview given by José Arthur Gianotti (Professor of Philosophy) to Julia Duailibi of theEstado de São Paulo, on August 08, 2009. For Arthur Gianotti, it is not role of the judiciary branch to impose restrictions on information 
publishing. On the 30, the Desembargador Dácio Vieira, from the Tribunal de Justiça do Distrito Federal, prohibited the Estado on publishing journalistic information about Fernando Sarney, son of the Brazilian Federal Senate's President, José Sarney (PMDB-AP), from whom he is a dear friend. "When you see judges who are taking part in the banquet, they perfectly understand they need to defend the banquet", he states. For the philosopher the fragile Brazilian democracy allows situations like this one. "We shall be always vigilant", said Gianotti, completing: "What we have here is a total and general disorder". Read the interview as follows:

What's your evaluation on the prohibition imposed to the daily news Estado de S Paulo on publishing informations concerning Sarney's son? First of all, this is within a general problem in Latin America, which is the threat on formal democracy, which is a democracy of rights. We pass through a time of development and growth, of Brazil in particular. A great number of citizens entered into the political system, and its representatives are people who were entirely out of traditional political life. And this people have no compromise with formal democracy. The issue on the censorship, to my opinion, is the same which is taking into the Senate's crisis, which is driving politics in Latin America into a total disorder. It is a world issue, but in Brazil it happens deeper.

Do you think it is up to the judiciary branch to impose restrictions on publishing informations of public interest? No, obviously not. It happens that, when judges take part in the banquet in Brasilia, they perfectly understand they have to defend the banquet.

Are the judiciary branch decisions somehow influenced by political issues? When overall decisions of the judiciary branch go to the Brazilian constitutional court, they are always influenced by the political game. The constitutional court is the place where law and politics bond, like anywhere in the world.

In Brazil, because it is a fresh democracy, does this influence occur more frequently? Yes, in Brazil we shall resist the best we can. We have to feel that this is not an epiphenomena (accessorial phenomena) also, it is not accidental. It is attached to the growth of citizenship in Brazil. In the way that an enormous disorder of people joined the market and begun to participate on daily political life, with their rights. These people as they got there, they begun to think in terms of immediate gains. They are not capable of feeling that an immediate gain may vanish in a further perspective. This lack of forecast, which is a trend mark of the Lula governmental term, tends to cause despise on formal democracy. If our representatives had a deeper political culture this wouldn't be happening.

How to conciliate individual freedoms and the right to information in a country where the judiciary branch is subject to political influence? Is there a need for new rules? No rule will solve the issue. The issue is that people begin to follow the rule and other people will complain when the rule is followed. There is always some bastard who is going to bypass the rule. What has to be done and it is being well done is the struggle against the restrictive order hardly and with the blessings of a right which is usually misinterpreted.

What lesson can the country take from episodes like this? That Brazilian democracy is very fragile. And that we shall be always watching.

This censorship links to times like in the military regime? I don't think so. In dictatorship the political process was another. There was a break of the democratic system. This is not what is happening now. What we have now is overall a total disorder. It reflects the enormous contrasts of Brazilian society today. It is the integration of this people in our daily life, publicly and politically. The Brazilian political institutions tend to strengthen with democracy's maturation?

Yes they do, but there are opposite tendencies also. There are countries which fail. Nothing leads us to say Brazil is going to succeed. See Argentina. It was a great country which lost track. Nothing is avoiding Brazil to follow on the same track. 
when the threat to freedom of the press doesn't comes from the state apparatus or the executive branch but from members within judiciary branch who should be guarding and protecting the constitution and its values, such as the freedom of the press. It is necessary to say that these are isolated situations but represent an unacceptable legal stand which should be harshly reproved by society and by the Judiciary branch itself.

\subsection{The 2009 daily newspaper $O$ Estado de São Paulo case}

Two cases decided by the Brazilian constitutional court - S.T.F. - Supremo Tribunal Federal- on 2009 frame the climax on prior censoring freedom of press: the A.D.P.F. $130^{36}$, which resulted in the declaration of the Brazilian Press Act as unconstitutional and the Reclamação $o^{37} \mathrm{n}^{0} 9.428$ with injunction claim, having as claimer reclamante ${ }^{38}$ - the daily newspaper O Estado de São Paulo, being this a constitutional action following the Ação de Descumprimento de Preceito Fundamental - A.D.P.F. constitutional action. The reclamação followed due to the transcendent procedural effects of the A.D.P.F.'s reasons beyond the action itself and by the fact of the losing votes of three Justices of the Brazilian constitutional court (S.T.F.) - Ministers Celso de Mello, Ayres Britto and Carmen Lúcia - have considered the general power of injunction on civil procedure given to judges and Appeal Court's Justices the new face of previous censorship and an obstacle to the development and exercise of freedom of press in the land.

That three justices minority block ${ }^{39}$ of the court defended a stand which reflects the constitutional understanding upon which this article focus, bringing to the light of academic debate new questions on the issue and some important observations made by the Court's Justices:a possible misuse of the legal institute of injunction on procedural law as a new form of oblique censorship to media in all forms is put into public

http://politica.estadao.com.br/noticias/geral,a-questao-da-censura-e-a-mesma-da-crise-dosenado,415599. Accessed on May 27, 2015.

36 A.D.P.F. is an abbreviation for AÇÃO DE DESCUMPRIMENTO DE PRECEITO FUNDAMENTAL. It is one of many constitutional actions designed to guarantee fundamental rights or constitutional values within the constitutional text. It is regulated by Law 9.882/99.

$37 \mathrm{MCRecl}$. Is an abbreviation for Medida Cautelar na Reclamação or 'injunction effect on Complaining Action'. It is the Brazilian equivalent to the German institute of the Verfassungsbeschwerde. Is one of many constitutional actions inserted on article 102, inciso I, alínea "i" of the Constitution, and regulated by article 13 of Law 8.038/90 - Procedures on Constitutional Court. It is designed to be proposed directly before the Constitutional Court (STF) as an action to preserve the authority of the Court's decisions which might not being complied by state authorities or civil entities.

38 Or: claimer.

39 The Brazilian constitutional court is composed by eleven justices. 
debate display. Such oblique misuse of the injunction procedural law appointed by the Court's Justices reveals how threatening is the situation within the Judiciary branch of the state, compromising the true defense of fundamental rights into personal opinions of local judges who sometimes might leave aside the compromise to defend the constitution. By doing so they alone overlap the "will of the constitution" ${ }^{40}$ to guarantee the freedom of the press. Maybe people should get more worried on trying to understand the reasons of the other justices not to take the same stand and think why they didn't see any constitutional violation.

Nevertheless, it is to be considered that the deployment of such legal measure shows how fragile our constitution is to be easily bypassed on its aim to guarantee fundamental rights. A simple reasoning which could be repelled bythe Judiciary branch anytime, but so far it was not. It is acceptable the idea the Brazilian Supreme Court is a political court and that its decisions many times bare political content, but the decision in the Medida Cautelar na Reclamação $\mathrm{n}^{\circ} 9.428$ shows how fragile the constitution is when politics get more ground than the democratic commitment with the law and the fundamental rights, even in the Supreme Court field ${ }^{41}$.

Until the emerging of cases similar to this the constitutional history of freedom of the press had logged threats coming mostly from the State apparatus - the Executive branch mostly. However, by bringing to the judiciary branch political issues which the Brazilian Congress didn't want to take full responsibility for the decision, the Judiciary branch begin to take a stand in the post 1988 constitutional and political scenario in Brazil as the main and most controversial source of legal restraining orders into freedom of the press. Some sectors of civilian society remnants of the oligarchic ruling families all across the land, this time more educated and enlightened in the legal matters may have identified the legal rhetoric and speech in court as the best way to hold their stands in the political ground by directly or indirectly interfering on high court decisions, 'wrapped' in the blanket of the new judicial branch activism. In such way a new brand of censorship took shape in the Brazilian democratic scenario. Judiciary branch censorship is a more considerable threat to democracy as we know than the prior State'scensorship mechanisms, flaring a political setback for Brazil and opening the gates of reshaped regimes which work under the rule

40 Expression used by Karl Loewenstein on his book "The normative strength of the constitution".

41 From another point of view, it is to remember how the German Weimar constitution of august 11,1919 was suspended by a simple interpretation of its article 48 . History teaches mankind so errors committed in the past shall not be repeated. Society should think over the creation of a judiciary compliance mechanism within the judiciary branch, following the example given by major private enterprises. 
of exception as became so present in Latin America's life in the last twenty years ${ }^{42}$.

Then, it is to be said the Court's final decision on the Medida Cautelar na Reclamação $\mathrm{n}^{\circ} 9.428$ points out possible case of prior censorship in the daily newspaper $O$ Estado de São Paulo. The alleged censorship is due to the publishing of many reports and journalistic covers about the entrepreneur Fernando Sarney, son of Senator José Sarney, then President of the Brazilian Senate. The newspaper issue indicated possible clues on his involvement in criminal actions. Such reports were based on information press releases of the Brazilian Federal Police after the Boi Barrica Operation. All information was obtained legally by the daily newspaper. There was no illegal disclosure of secret or classified information. Right after that and due to the repercussion of the journalist cover across the land the sanctions to the newspaper begun. A restraining order was issued to prohibit any information disclosure on the case by a Justice belonging toTribunal de Justiça do Distrito Federal at the capital city Brasília, who was appointed to office a few years before by Senator José Sarney.

Following the legal procedure as set by the constitution and co-related legislation it was believed by the newspaper's lawyers the Reclamação constitucional and the injunction claim would cease the Appeal Court's decision setting up censorship on that journalistic cover issue. Instead of the expected result, the succession of events along months showed clearly an enormous disappointment displaying how Democracy and Fundamental Rights in Brazil were weakened. As notes BUCCI (2009), in face of the clear movements of oligarchic sectors in the political and legal backstage it is possible to see how well coordinated is the reaction to the democratic project by some sectors of civil society in Brazil. Despite the teaching of democratic culture and republicanism at universities, in the real world the project of a Republic based on the French model is still on hold position.

The will of the Brazilian constitution prohibits censorship in all forms, but sets up a mechanism to punish those who exceed the limits of a free press with the possibility of civil and criminal actions in the form of the Brazilian defamation law. This legal breach in the law, which allows the misuse of injunction tends to attach on the Judiciary branch the label of the new censor. Censorship can be understood as a prior judgement of value which is done by someone referring to information content, further determining its reformulation or suppression. The intention is to erase the idea or the concept from the world of facts, because it is contrary to the group in power. It brings naturally the concept that bares a moral or ideological burden. A democratic society based upon the

42 See ANASTAPLO (2002). 
concept of tolerance and pluralism of ideas, religions, ethnical groups and political concepts shall create and preserve a neutral field where all members of society may live peacefully side by side. Censorship is a concept opposite and contrary to freedom of press. It is up to the readers to comment and 'judge' the publishing, not a task for a censor, political committee or even less the State or its branches.

New forms of by passing the constitutional guarantees are being built in Brazil by many self-denominated democracy defenders, such as the alleged needed "content adequacy" into a temporary political party idea in office. It is remarkable how such pedestrian, misconceptions and flat ideas on democracy insist on proliferate in Latin America. The use of legal euphemisms brings back trashy recycled concepts used in the old times of the Soviet Union and its satellites. As if the Pravda or the Granma were the bearers of truth and consensus in society. The fall of the countries behind the iron curtain on 1989 culminating with U.S.S.R. has shown they were wrong. The model of free press under liberal values is still valid and shall be defended.

The understanding in the Brazilian constitutional law as set by AFONSO DA SILVA $(1998)^{43}$ on the issue is that fundamental rights are plain on producing immediate effects in the world of facts as seek by the 1986 constitutional assembly which draft the text. Most of the fundamental rights do not need any piece of further legislation to reach plain effect. So is the freedom of the press according to article 5 of the constitution, amongst other fundamental rights with freedom related. Furthermore, paragraph 2 of article $220^{44}$ from the constitution reinforces this understanding. Then, it rests more than clear how confusing is the effect of the Brazilian Constitutional Court decision on the exercise of freedom of the press.

As a model for the Brazilian constitutional law freedom of the press content's on its extension is given by FISS (2009) when analyzing the U.S. Supreme Court Pentagon Papers case 1971 decision. The case shows how important was for American civil society to know all details of public life, including the status of wars raged by their State abroad, once it reaches and causes effects on people's lives. If someone is going to die for the State, then there is the constitutional right to know how war is being conducted by the State and military staff. The useless sacrifice of lives shall be avoided as it was done in old Athens when citizens gathered in the $\boldsymbol{a g o r a}^{45}$ had to decide all concerning their city -

43 See on the same path Sarlet (2009) and Gomes Canotilho (1993).

44 Article 220 of the Brazilian 1988 constitution - Manifestation of thinking, the creation, expression and the information, under any form, procedure or mean will not suffer any sort of restriction, observed the constitution.

$\S 2^{\circ}-$ It rests prohibited every and any censorship of political, ideological and artistic nature.

45 'Square' in greek. 
the polis ${ }^{46}$. The press in all sorts of media channels shall develop its job highly compromised with ethical values and take full responsibility for to what is printed or published. Abusive use of the press calls for law enforcement in the terms of the Brazilian defamation law ${ }^{47}$.

Based on MORANGE's (1985) reflections on the issue, it is possible to note Brazil is passing through a temporary setback on this fundamental right in particular, because if Brazilian people still have to struggle politically to live as a whole thefirst fundamental rights generation such as protection to life, physical integrity, public liberties linked to religion, political opinion and other kinds of civil rights, it is sad to see we are still living two hundred years in the past. Press censorship is no longer acceptable, under any circumstances.

So, it is more than fair to sense through it how much democracy in Brazil has to mature still.The debate is framed by those two Constitutional Court's decisions (A.D.P.F. 130-D.F. and Medida Cautelar na Reclamação 9.428), both from 2009. Their content reflects the Brazilian Constitutional Court's main reasons on freedom of press and censorship. The Reclamação is directly attached to the A.D.P.F. by a thematic bond, i.e. freedom of the press, once the background debate is freedom of press. The Reclamação was proposed as a constitutional action in order to preserve the authority of the decision set by the Brazilian Constitutional Court, considering the so called transcending effects of the determining reasons' contained in the decision, as a procedural effect adopted by the Brazilian Constitutional court in order to wide up the constitutional control.

By the occasion of the A.D.P.F. 130-D.F. judgement, the Brazilian Constitutional Court declared the Press Act - Lei 5.250/67 unconstitutional. The Brazilian Constitutional Court's Justice in charge to report the case for his fellow justices on the court's plenarium, Min. Ayres Brito stated:

The normative core of the Brazilian constitution equalizes freedom of journalistic information and freedom of the press, repelling any form of prior censorship to a right which is sign and guarantee of the worshipped dignity of the human being, as well as the most developed state of the civilization. [...]. There is no such thing as freedom of the press by the half or under the forceps effect of prior censorship, including one coming from the judiciary branch of the state, otherwise approaching the unconstitutional field of legal jugglery. (Report of A.D.P.F. 130-D.F., pages 4 and 5)

46 'City' in greek.

47 See Liern (2002). The Brazilian defamation law also. 


\subsection{New borders for the freedom of press under the post 2003 non liberal government}

By the occasion of judgement of A.D.P.F. 130 - D.F., Minister Celso de Mello made a reference to the Hemispheric Conference on Freedom of the Press, occurred on 1994 in Mexico. The Conference ended with the Chapultepec Declaration signing between many principles and values the following applied to the issue focused on this paper:

II - Every person has the right to search and to receive information, to express opinions and to spread them freely. Nobody may restrain or deny these rights.

$V$ - The previous censorship, the restrictions on mean circulations or the publishing of its messages, the arbitrary imposition of information, the creation of obstacles to the free informative flow and limitations to the free exercise and movement of journalists oppose directly the freedom of press. (sic) (ADPF 130-DF, p. 146)

The Brazilian Constitutional Court's Justice Minister ${ }^{48}$ Celso de Mello built again an expressive and historic defense on freedom of the press, by the occasion of the injunction request in the Reclamação 9.428 , on December 10, 2009. When aligning his reasons of vote with Minister Ayres Brito, he stated that press shall be free of any kind of restraining, limitation or chains from any State branch in order to exist fully on its major task to strength democracy.

On M.C. Reclamação no 9.428, Minister Celso de Mello states:

Nowadays, the censorship, and I identify it so, has been so abusive on the behavior of certain judges and courts in our country. Nowadays, the general power of injunction ${ }^{49}$ is the new name for the judiciary censorship in our country. And this is very

48 In Brazil, the Constitutional Court's members have the status of State Minister.

49 Just as a brief information for our foreign reader, the general power of injunction as we may call it so in english is a specific procedure in procedural law designed to prevent potential damage or a damage in progress, before proposing the action, which might take more time than needed to stop the damaged, into a point where it is irreversible. Judges and courts are invested of such power, once the reasons are well presented and the injunction order seems necessary. Sometimes a monetary guarantee is asked by the court from the claimer, which serves as insure for the effects of the injunction order. 
serious, because it makes us to turn back into our colonial past (sic).

The statement above demonstrates that more than twenty seven years after the 1988 constitution it is possible to identify a breach in the legal system which may put into 'suspension' or 'restriction' some fundamental rights inserted in the constitution. Such not so openly declared effects do not come from the historical 'suspect' Executive branch, but this time from the Judiciary branch. The Judiciary branch should rethink as a whole its role on the democratic project of nation in progress in Brazil. Following, it should propose to the Legislative branch reforms on the injunction legislation in order to limit such kind of decisions which turn the will of the constitution in a joke before the eyes of the people. Judges are citizens within a Republic and they shall behave within the constitutional frame, being accountable for their behavior to society also.

\section{ARE We TRULY LIVING IN A DEMOCRACY?}

This question will not meet an answer on many countries in Brazil's neighborhood for many reasons which are not object of this paper. For now it is possible to reply affirmatively that Brazil is living a work in progress democracy. But it is neither fail safe nor consolidated yet, the way I see it. Many issues in the 1988 Constitution are a legal nobody's land still waiting for further pieces of legislation to put it entirely on the track. Considering Brazilian constitutional historical panorama and the political events which took place in the country between 1934 and 1988, it is clearly possible to admit the theory that a new constitution might appear in the horizon before the 1988 is fully regulated by all sorts of acts needed.This is a question frequently made by my students at Law School during my History of Brazilian Law classes at University ${ }^{50}$. I always have to explain them enumerating a number of historical and political facts not lived by them and neither by me, what astonishes them is how far it goes back to the past. Because of their youth they look at me with some sort of skepticism and resilience to accept the explanation.

Anyway, if it happens there is much few to do to avoid it. The wheels of history and the will of politicians are unstoppable. What worries the most is the historical resistance to embrace a liberal democratic project of nation for Brazil. The lack of a serious constitutional culture directly affects both legal and economic stability and people's lives also. Not far back in the past Germany fall in the hands of a certain

50 U.F.R.R.J. - Universidade Federal Rural do Rio de Janeiro= National Rural University at Rio de Janeiro. Law School. 
Nazi party, which enjoyed and took advantage of such constitutional breaches and democratic weaknesses to suppress democracy and to install a totalitarian regime. Times, places and villains are different but the threat to democracy remains. It is possible to find some of them along the Brazilian border.

Democracy in Brazil will be more solid as more education is given to the people. However, lack of a good public education is a permanent debt in the country. Moreover, the lack of liberal values demonized by its opponents keep us away of this political democratic experiment. The anti-liberal pupils create a new language, where prior censorship to freedom of the press becomes acceptable into the eyes of careless citizens through the political euphemism "content adjustment" for the press, in order to slightly restore State censorship mechanisms to put the press on a leash. It is up to society, its institutions and the Brazilian Constitutional court to become aware of such threat and do whatever they can do protect democracy.

\section{Conclusions}

It is important to spread the knowledge on the issue above, so the Brazilian people may be aware of the threatsgetting near the constitution. The values of the Brazilian independence insurrection of Minas Gerais happened in the XVIII century shall not be forgotten: libertas quae sera tamen. The insurrection against the Portuguese Crown equalizes in a much smaller scale the same liberal values of the French and American Revolution. The first word of the motto in Latin is 'freedom'. For how long shall we still wait to live in a country where the whole meaning of freedom is guaranteed by the State and known by all the People is a question yet to be answered. Press has been a bulk of freedom in the struggle against monarchist, dictatorial and totalitarian regimes since the XVIII century. In a recent past some South American countries are passing through a hard test on their political democratic regimes, sometimes failing to guarantee the most basic freedoms. It is time to open widely the eyes to what is happening around us and become aware for the importance of both democracy and constitution. May the example of the United States Constitution's first amendment inspire Brazil in our path to secure democracy in the forthcoming years.

\section{REFERENCES}

AFONSO DA SILVA, José. Aplicabilidade das normas constitucionais. 3. ed. São Paulo: Malheiros, 1998.

ALEXY, Robert. Teoria dos direitos fundamentais. São Paulo: Malheiros, 
2008.

ALLAND, Denis et RIALS, Stéphane. Dictionnaire de la culture juridique. Paris: Quadrige/Lamy-PUF, 2003.

ALVES MACIEL, Débora. Sentidos da judicialização da política: duas análises. Available at: www.scielo.br/pdf/m/n57/a06n57.pdf. Access onMarch 2, 2010.

ANASTAPLO, George. Censorship. In: The new encyclopaedia britannica. 15. ed. Chicago: Encyclopaedia Britannica, 2002. Vol 15.

BARBOSA, Cláudia Maria. O processo de legitimação do poder judiciário brasileiro. Available at :www.conpedi.org/manaus/arquivos/ Anais/Claudia\%20Maria\%20Barbosa.pdf. Access January, 2010.

BARROSO, Luís Roberto. Judicialização, ativismo judicial e legitimidade democrática.Available at: www.oab.org.br/oabeditora/ users/revista/1235066670174218181901.pdf. Accesson January, 2010.

BRASIL. Supremo Tribunal Federal. Brasília. ADPF 130 - DF, de 30/04/2009.Available at: www.stf.jus. $\mathrm{br} / \mathrm{id}=605411 \&$ tipo $=\mathrm{AC} \&$ descrição=inteiro $\% 20$ teor $\% 20 \mathrm{ADPF} \% 20$ /\%20130. Access March 11, 2010.

BRASIL. Supremo Tribunal Federal. Brasília. MCRecl. 9428, de 10 de dezembro de 2009.Available at: /www.stf.jus.br/arquivo/cms/ noticiaNoticiaStfArquivo/anexo/Rc19428RelVoto.pdf. Accesson March 11, 2010.

BRASIL. Supremo Tribunal Federal. Brasília. Informativo n. 576, 2226 fev. 2010.Available at: http://www.stf.jus.br//arquivo/informativo/ documento/informativo576.htm. Access march 11, 2010.

BUCCI, Eugenio. A imprensa e o dever de liberdade. São Paulo: Contexto, 2009.

CASTANHO DE CARVALHO, Luís Gustavo Grandinetti. Liberdade de informação e o direito difuso à informação verdadeira. 2. ed. Rio de Janeiro: Renovar, 2003.

CITTADINO, Gisele. Poder judiciário, ativismo judicial e democracia. In:SEMINÁRIO TEMÁTICO CONTROLES DEMOCRÁTICOS E RESPONSABILIDADE PÚBLICA, no XXV Encontro da Associação Nacional de Pós-graduação e Pesquisa em Ciências Socias (ANPOCS), Caxambu, Minas Gerais, 16-20 out. 2001.

DE SOUZA, Sérgio Ricardo. Controle judicial dos limites constitucionais à liberdade de imprensa. Rio de Janeiro: Lumen, 2008.

DE SOUZA SANTOS, Boaventura. A judicialização da política. Available at:www.ces.uc.pt/opinião/brs/078.php. Access March 3,2010. 
Freedom of Press and Judiciary Censorship in Brazil - Peri Guedes

FISS, Owen M. Liberalism divided - Freedom of speech and the many uses of state powers. Boulder: Westview, 2009.

FISS, Owen M. The irony of free speech. London: Harvard University Press, 1996.

GOMES CANOTILHO, José Joaquim. Direito constitucional. Coimbra: Almedina, 1993.

LIERN, Göran Rollnert. La libertad ideológica em la jurisprudencia del Tribunal Constitucional (1980-2001). Madrid: Centro de Estudios Políticos y Constitucionales, 2002.

MILTON, John. Areopagítica - Discurso pela liberdade de imprensa ao parlamento da Inglaterra. Rio de Janeiro: Topbooks, 1999.

MOON, Richard. The constitutional protection offreedom of expression. Toronto: University of Toronto Press, 2000.

MORANGE, Jean. Droits de l'homme et libertés publiques. 5. ed. Paris: PUF, 1985.

RABAY GUERRA, Gustavo. A expansão do poder judicial no constitucionalismo democrático: distorção sistêmica ou necessidade contemporânea?Available at: www.buscalegis.ufsc.br/revistas/files/ journals/2/articles/32552/public/32552-39665-1-PB. Access March 3, 2010.

RIZZINI, Carlos. Liberdade de imprensa. São Paulo: Mantiqueira, 1998.

RUFINO DO VALE, André. Eficácia dos direitos fundamentais nas relações privadas. Porto Alegre: Sérgio Fabris, 2004.

SARLET, Ingo Wolfgang. A eficácia dos direitos fundamentais. 10. ed. Porto Alegre: Livraria do advogado, 2009.

SIQUEIRA CASTRO, Carlos Roberto. A constituição aberta e os direitos fundamentais. Rio de Janeiro: Forense, 2003.

RIBAS VIEIRA, José; LACOMBE CAMARGO, Margarida Maria e GARRIDO DA SILVA, Alexandre. Brasil nas mãos dos tribunais. Revista VERSUS. Rio de Janeiro, ano I, n. 2, pp. 75-84, ago. 2009.

RIBAS VIEIRA, José (Coord.), SOARES BENTES, Hilda Helena (Coord.), LACOMBE CAMARGO, Margarida Maria (Coord.) e GOMES, Maria Paulina (Coord.). Direitos à intimidade e à vida privada. Curitiba: Juruá, 2008.

WERNECK VIANA, Luís. A judicialização da política e das relações sociais no Brasil. Rio de Janeiro: Revan, 1999.

WERNECK VIANA, Luís. Entre princípios e regras - cinco estudos de 
caso de ação civil pública.Caderno CEDES. Rio de Janeiro, ano I, n. 1, mar. 2005.

WERNECK VIANA, Luís. Dezessete anos de judicialização da política. Available at:www.scielo.br/pdf/ts/v19n2/a02v19n2.pdf. Access March 3, 2010 .

WERNECK VIANA, Luís. O ativismo judicial mal compreendido. Boletim CEDES [on-line]. Rio de Janeiro, jul./ago. 2008, pp. 03-05. Available at: http://www.cedes.iuperj.br. ISSN: 1982-1522. Access February 24, 2010. 